\title{
Feeding behaviors of feedlot bulls fed concentrate levels and babassu mesocarp meal ${ }^{1}$
}

\author{
Rossini Sôffa da Cruz ${ }^{2}$, Emerson Alexandrino², Regis Luis Missioº ${ }^{2}$, José Neuman Miranda Neiva ${ }^{2}$, \\ João Restle ${ }^{2}$, Jonahtan Chaves Melo², Antonio de Sousa Júnior ${ }^{2}$, José Messias de Resende ${ }^{2}$ \\ ${ }^{1}$ Research funded by Capes. \\ 2 Universidade Federal do Tocantins, Campus Araguaína.
}

\begin{abstract}
The objective of the present study was to evaluate the feeding behavior of feedlot Nellore bulls fed two levels of concentrate (650 and $710 \mathrm{~g} / \mathrm{kg}$ dry matter) with or without the inclusion of $350 \mathrm{~g}$ babassu mesocarp meal $/ \mathrm{kg}$ dry matter in the concentrate. Twenty-eight animals at 18 months of initial age and $356.66 \pm 19.25 \mathrm{~kg}$ initial body weight were used. A completely randomized design was used with treatments in a $2 \times 2$ factorial arrangement. Increase in concentrate level from 650 to $710 \mathrm{~g} / \mathrm{kg}$ dry matter did not change the feeding time, of 194.41 and 189.64 minutes/day, respectively. The inclusion of $350 \mathrm{~g}$ babassu mesocarp meal/ $\mathrm{kg}$ dry matter in the concentrate increased the feeding time from 173.92 to 210.12 minutes/day, ensuring similar energy intake in relation to the diets without this byproduct. Rumination time was not changed by increasing the concentrate level in diets with $350 \mathrm{~g}$ babassu mesocarp meal/kg dry matter in the concentrate, with average values of 420.48 and 398.09 minutes/day for the levels of 650 and $710 \mathrm{~g}$ concentrate/kg dry matter, respectively. However, in diets without babassu mesocarp meal, the rumination time was reduced by the concentrate level, with average values of 452.14 and 409.76 minutes/day for 650 and $710 \mathrm{~g}$ of concentrate/ $\mathrm{kg}$ dry matter, respectively. Time spent on other activities increased from 810.23 to 860.00 minutes/day with increase in the concentrate level, which was not changed in the diets containing babassu mesocarp meal. The inclusion of babassu mesocarp meal in the diet altered the feeding behavior of feedlot cattle, due to the need to increase the feeding time to maintain the energy intake.
\end{abstract}

Key Words: biofuels, feed efficiency, feeding time, idle, rumination

\section{Introduction}

Feedlot as a strategy for feeding the cattle herd during forage shortage has become infeasible because of increase in the price of the grains used in animal feeding. At the time when Brazil encouraged the use of grain-based diets, there was an increase in the international corn price due to biofuel production by some countries such as the USA, which set aside $40 \%$ of their production for this purpose (Wilkinson, 2010). Thus alternative feedstuffs, such as byproducts from the biofuel agroindustry that can partially substitute corn and/or soybean meal in the diet may represent cost reduction in the feedlot.

Byproducts available in the northern region of Brazil include those derived from processing the babassu palm nut for biofuel production. Among these byproducts, the babassu mesocarp meal stands out, with limited information on its use in cattle feed. Miotto (2011) studied the replacement of corn by babassu mesocarp meal (0.250.500.750 and $1000 \mathrm{~g} / \mathrm{kg}$ dry matter) in cattle diet and observed that this byproduct can substitute up to $50 \%$ corn grain without altering the animal performance, showing the possibility of its use in ruminant feeding. Nevertheless, little is known about the effects of including this byproduct in the diet on ruminant feeding behavior.

Feeding behavior can be characterized by the uneven distribution of a succession of defined and discrete activity periods, classified as ingestion, rumination and idleness (Penning et al., 1991). Ingestion is the most important of these activities because ruminants respond differently to the different types of foodstuffs and diets, altering their production levels and feeding behavior (Pires et al., 2001). Thus the objective of the present study was to assess the feeding behavior of Nellore bulls fed in a feedlot with two concentrate levels associated, or not, to inclusion of babassu mesocarp meal in the concentrated fraction of the diet.

\section{Material and Methods}

The study was carried out from June 30th to September 21 st, 2010 at the Escola de Medicina Veterinária e Zootecnia at Universidade Federal do Tocantins, Campus de Araguaína, 
located at $07^{\circ} 11^{\prime} 28^{\prime \prime}$ south latitude and $48^{\circ} 12^{\prime} 26^{\prime \prime}$ west longitude. The mean values for the maximum, minimum and mean temperatures, relative air humidity and rainfall during the experimental period were $35.5,17.8$ and $25.67{ }^{\circ} \mathrm{C}$, $53.67 \%$ and $0.33 \mathrm{~mm}$, respectively.

Twenty-eight Nellore bulls of 21 months of initial age and $356.66 \pm 19.25 \mathrm{~kg}$ initial body weight were used. The animals were weaned at seven months and kept during the growing phase on Brachiaria brizantha cv. Marandu pasture with mineral supplementation. At the end of the growing period (start of the experiment) the animals were confined individually in partially covered $14 \mathrm{~m}^{2}$ stalls with a concrete floor, equipped with individual drinkers and feeders.

Prior to the experimental period, the animals were adapted to the diets and facilities for seven days. The experimental diets (Table 1) were balanced for a 1,200 g/day weight gain, estimating intake of $24 \mathrm{~g}$ /day body weight (NRC, 1996). The feed intake was recorded daily by weighing the diet supplied and leftovers. The feed supply was kept $10 \%$ above the voluntary intake, divided in two daily meals ( 8 a.m. and 2 p.m.). The roughage used during the feedlot period was Brachiaria brizantha cv. Piatã silage harvested and disintegrated ( 8 to $10 \mathrm{~mm}$ particles) at the initial flowering stage of the plants and the babassu mesocarp meal was obtained by extraction of the peel of the babassu fruit separated from the epicarp, which was then ground (Table 2).

To determine the chemical composition of the diets (Table 3) feed samples were collected weekly, packed, labeled and frozen at $-20^{\circ} \mathrm{C}$. At the end of the experiment, the samples were thawed and a composite sample was made per period, oven-dried $\left(55^{\circ} \mathrm{C}, 72\right.$ hours $)$ and processed in a Willey-type grinder with a $1 \mathrm{~mm}$ mesh sieve.

The contents of dry matter (DM), ether extract (EE) and crude protein $(\mathrm{CP})$ were determined according to the AOAC (1995). The neutral detergent fiber (NDF) and lignin were determined according to Van Soest et al. (1991), and the NDF was corrected for ash and protein (NDFap) according to Silva \& Queiroz (2002). The acid detergent fiber (ADF) was determined according to Van Soest (1973). The total carbohydrates (TC), non-fibrous carbohydrates (NFC) and total digestible nutrients (TDN) were determined according to Sniffen et al. (1992), in which TC $=100-(\mathrm{CP}+\mathrm{EE}+\mathrm{MM})$,

Table 1 - Percentage composition of the experimental diets

\begin{tabular}{|c|c|c|c|c|}
\hline \multirow[t]{2}{*}{ Ingredients (g/kg DM) } & \multicolumn{4}{|c|}{ Diets $^{1}$} \\
\hline & $650 \mathrm{C} / 0 \mathrm{BMM}$ & $710 \mathrm{C} / 0 \mathrm{BMM}$ & $650 \mathrm{C} / 350 \mathrm{BMM}$ & $710 \mathrm{C} / 350 \mathrm{BMM}$ \\
\hline Silage $^{2}$ & 350.0 & 290.0 & 350.0 & 290.0 \\
\hline Babassu meal ${ }^{3}$ & - & - & 226.8 & 254.6 \\
\hline Ground corn & 549.7 & 628.0 & 324.6 & 367.4 \\
\hline Soybean meal & 74.7 & 58.0 & 66.7 & 57.0 \\
\hline Urea & 9.1 & 8.8 & 15.1 & 15.0 \\
\hline Calcitic limestone & 8.2 & 7.8 & 8.1 & 7.7 \\
\hline Mineral nucleus ${ }^{4}$ & 5.1 & 4.4 & 5.1 & 4.8 \\
\hline Common salt & 2.1 & 2.0 & 2.0 & 1.9 \\
\hline Ammonia sulphate & 0.9 & 1.0 & 1.7 & 1.7 \\
\hline
\end{tabular}

Table 2 - Chemical composition of the roughage and concentrate ingredients

\begin{tabular}{|c|c|c|c|c|}
\hline Item (g/kg DM) & Silage $^{1}$ & BMM & GC & SM \\
\hline Dry matter ${ }^{2}$ & 400.0 & 854.9 & 853.7 & 871.3 \\
\hline Crude protein & 55.5 & 31.4 & 84.5 & 442.8 \\
\hline NDFap & 676.8 & 275.3 & 177.4 & 64.9 \\
\hline Acid detergente fiber & 413.4 & 203.0 & 116.6 & 37.0 \\
\hline Lignin & 41.0 & 118.7 & 18.7 & 18.3 \\
\hline Total carbohydrates & 873.9 & 921.0 & 832.9 & 470.7 \\
\hline Non-fibrous carbohydrates & 197.1 & 645.7 & 755.5 & 405.8 \\
\hline Total digestible nutrients & 560.2 & 614.6 & 879.7 & 784.5 \\
\hline
\end{tabular}

BMM - babassu mesocarp meal; GC - ground corn; SM - soybean meal; DM - dry matter; NDFap - neutral detergent fiber corrected for ash and protein.

1 Brachiaria brizantha cv. Piatã.

$2 \mathrm{~g} / \mathrm{kg}$ natural matter. 
Table 3 - Chemical composition of the experimental diets

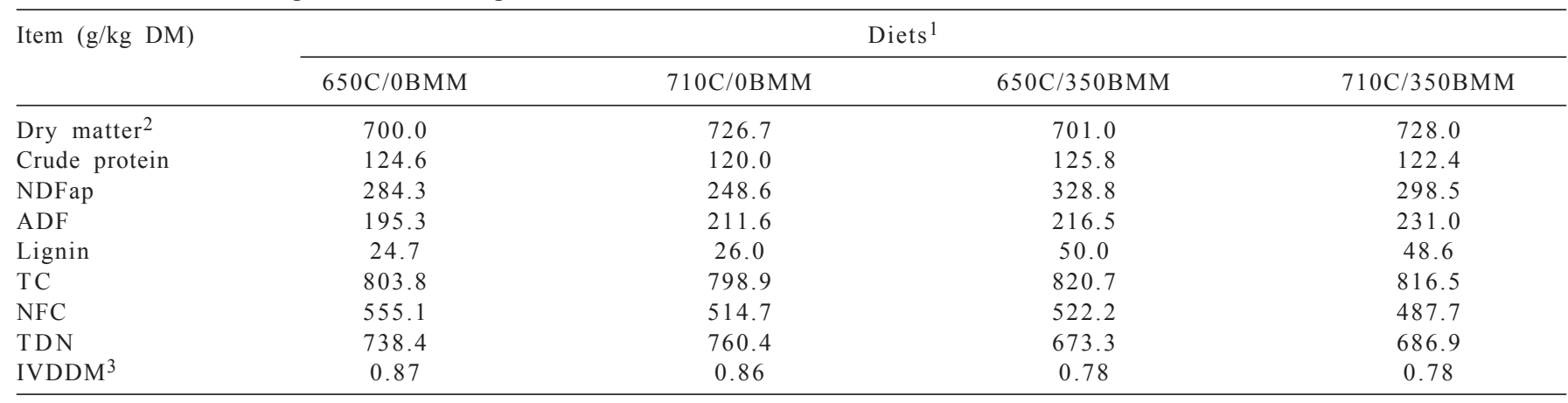

NDFap - neutral detergent fiber corrected for ash and proteins; ADF - acid detergent fiber; TC - total carbohydrates; NFC - non-fibrous carbohydrates; TDN - total digestible nutrients; BMM - babassu mesocarp meal.

${ }_{1}^{1} 650 \mathrm{C}$ and $710 \mathrm{C}-650$ and $710 \mathrm{~g} / \mathrm{kg} \mathrm{DM}$ concentrate in the diet, respectively; 0 BMM and $350 \mathrm{BMM}-0$ and $350 \mathrm{~g} / \mathrm{kg}$ DM babassu mesocarp meal in the concentrate, respectively.

$2 \mathrm{~g} / \mathrm{kg}$ natural matter.

3 In vitro dry matter digestibility, $\mathrm{kg} / \mathrm{kg}$ DM (Tilley \& Terry, 1963).

$\mathrm{NFC}=\mathrm{TC}-\mathrm{NDF}$ and $\mathrm{TDN}=$ digestible $\mathrm{CP}+$ digestible $\mathrm{NDF}$ + digestible $\mathrm{NFC}+(2.25 \times$ digestible EE $)$.

The feeding behavior data were collected during the feedlot period, totaling six days, in which in each experimental period, 48 hours of consecutive visual assessment were carried out (Martin \& Bateson, 1986), with 5 min intervals. The feeding times, rumination and other activities (idleness and sleeping) and frequency at the drinker were recorded. The mean of the number of chews per cud and the mean time spent on the chews of cud were obtained in four eight-hour periods, for two days, nine values per period, and three values were recorded distributed from 10 to midday, 2 p.m. to 4 p.m. and 6 p.m. to 8 p.m., using a digital stopwatch as proposed by Bürger et al. (2000).

The following ratios were determined from the variables intake and feeding behavior (Polli et al., 1996; Bürger et al., 2000): feeding efficiency (DM intake/feeding time); DM rumination efficiency (DM intake/rumination time), NDF rumination efficiency (NDF intake/rumination time), daily chewing time (feeding time plus rumination time), daily ruminated cuds (rumination time/chewing time per cud).

The number of chews/day was determined by multiplying the number of chews per cud and the number of daily ruminated cuds (Missio et al., 2010). The feeding frequency was determined from the assessment of the feeding time (number of times that the animals went to the feeding trough) and the number of meals/day, considering $10 \mathrm{~min}$ as minimum time for this activity.

A completely randomized design was used with the treatments in a $2 \times 2$ factorial arrangement (two levels of concentrate and two levels of babassu mesocarp meal inclusion). The data were submitted to analysis of variance and the Pearson correlation. When the interaction between the factors studied was significant, the means were compared by Tukey's test, considering $\alpha=5$. The statistical procedures were carried out using the PROC GLM procedure (Statistical Analyses System, version 8.02). The mathematical model was represented by: $\gamma_{\mathrm{ij}}=\mu+\tau_{\mathrm{i}}+£_{\mathrm{j}}+$ $\left(\tau^{*}\right)_{\mathrm{ij}}+\varepsilon_{\mathrm{ij}}$, in which: $\gamma_{\mathrm{ij}}=$ dependent variable; $\mu=$ general mean; $\tau_{\mathrm{i}}=$ effect of the concentrate level of the diets; $£_{\mathrm{j}}=$ effect of the babassu mesocarp meal level in the concentrate; $(\tau * £)_{\mathrm{ij}}=$ interaction between factor $\mathrm{i}$ and factor $\mathrm{j} ; \varepsilon_{\mathrm{ij}}=$ residual experimental error.

\section{Results and Discussion}

The feeding time varied independently in function of the factors assessed, and was not altered $(\mathrm{P}>0.05)$ by the concentrate level of the diet (Table 4). However, this activity was increased by including babassu mesocarp meal, reflecting the greater dry matter intake in these diets. Corroborating, Miotto (2011) stated that substituting corn with babassu mesocarp meal raised the feeding time because it increased the dry matter intake.

The increase in feeding time in the diets containing babassu mesocarp meal may have been associated to the need of animals to increase feed intake due to decrease in the energetic concentration in the diets resulting from the inclusion of this byproduct (Table 3 ). These assumptions are in line with Hodgson (1990), who stated that ruminants adapt to feeding conditions and modify their behavior to reach and maintain a determined intake level, compatible with their nutritional requirements.

The lack of variation in feeding time with the increase in the level of concentrate (Table 4) may have been associated to the small difference $(9,2 \%)$ between the proportions of concentrate used. Most studies that assess concentrate levels in cattle diets observe decrease in feeding time in 
Table 4 - Variables related to nutrient intake and feeding time according to the factors assessed

\begin{tabular}{|c|c|c|c|c|}
\hline $\mathrm{BMM}$ in the concentrate $(\mathrm{g} / \mathrm{kg} \mathrm{DM})$ & \multicolumn{2}{|c|}{ Concentrate level in the diet $(\mathrm{g} / \mathrm{kg} \mathrm{DM})$} & Mean & CV $(\%)$ \\
\hline \multicolumn{5}{|c|}{ Dry matter intake, $\mathrm{kg} /$ day } \\
\hline 350 & 10.20 & 10.59 & $10.40 \mathrm{~A}$ & \\
\hline Mean & 9.88 & 10.02 & 9.95 & \\
\hline 350 & 3.59 & 3.43 & $3.51 \mathrm{~A}$ & \\
\hline Mean & $3.21 \mathrm{a}$ & $2.93 b$ & 3.08 & \\
\hline \multicolumn{5}{|c|}{ Digestible energy intake, Mcal/day } \\
\hline 0 & 31.06 & 31.66 & 31.36 & \\
\hline 350 & 30.62 & 31.95 & 31.29 & 9.08 \\
\hline Mean & 30.84 & 31.81 & 31.33 & \\
\hline
\end{tabular}

CV - coefficient of variation; BMM - babassu mesocarp meal; DM - dry matter.

Means followed by different letters (uppercase in the column and lowercase in the row) differ $(\mathrm{P}<0.05)$ by Tukey's test.

function of the increase in the concentrate content in the $\operatorname{diet}$ (Bürger et al., 2000; Silva et al., 2005; Missio et al., 2010), a fact associated to the greater energetic density/bite. On the other hand, increase in the feeding time was observed because of the increase in the roughage content in the diet, which was associated to the increase in neutral detergent fiber content and decrease in the energetic content of the diets (Beauchemin, 1991; Dado \& Allen, 1995; Ramonet et al., 1999).

Feeding time presented 0.38 correlation with neutral detergent fiber intake $(\mathrm{P}<0.05)$ (Table 5), which is in line with the results reported by Dado \& Allen (1995). The association of feeding time with neutral detergent fiber intake was related to the increase in feed intake that occurred in the diets containing babassu mesocarp meal, resulting from the energetic requirement of the animals, the energetic content of the diets and the increase in neutral detergent fiber caused by this by-product. Araújo et al. (1998) reported that in animals fed diets that provided high nutrient supply, where the fibrous fraction was small and did not affect intake, intake is controlled by the energetic requirement of the animal. In this case, neutral detergent fiber was positively correlated with intake because, as the fiber in the diet increases, digestibility decreases and the animal needs to ingest more to meet its energy requirement. In this sense, the inclusion of $350 \mathrm{~g} /$ day babassu mesocarp meal dry matter in the concentrate resulted in a $9.7 \%$ average decrease in the in vitro digestibility of the diets (Table 3 ).

Although feeding time is considered the main activity in feeding behavior, responsible for the quantity of feed ingested, no correlation of this activity with dry matter intake was observed ( $P>0.05$; Table 5). However, feeding time was correlated $(\mathrm{P}<0.05)$ with frequency at the feeder $(\mathrm{r}=0.29)$ and number of meals $(\mathrm{r}=0.54)$, indicating indirect association between intake and feeding time. The results of the present study were in line with those obtained by Pinto et al. (2010), who assessed the feeding behavior of feedlot bulls fed diets based on sorghum silage and sugarcane and did not observe association between feeding time and dry matter intake. These authors emphasized that the feeding time could not be used as an indicator of feed intake, because several factors are related both to dry matter ingestion and the characteristics of the feeding behavior and rumination, such as the physical and chemical properties of the diet, digestibility and degradability of the feeds and the individual characteristics of the animals.

Feeding frequency and number of meals were lower for the diets that associated the lowest concentrate level and no babassu mesocarp meal in the concentrate (Table 6). These results may have been associated with a combination of factors, especially the energetic demand of the animals that reached satiety because of the greater energetic density of the diets with a high level of concentrate and the greater participation of neutral detergent fiber coming from the forage in the diets with a lower concentrate level. These interferences were shown by the correlation $(\mathrm{P}<0.05)$ of number of meals with neutral detergent fiber intake $(r=0.31)$, feeding time $(r=0.54)$ and rumination time $(r=-0.22)$.

Feeding efficiency was influenced $(\mathrm{P}<0.05)$ only by the level of babassu mesocarp meal and decreased with the 
Table 5 - Correlation matrix for feeding behavior characteristics

\begin{tabular}{|c|c|c|c|c|c|c|c|c|c|c|c|c|c|c|}
\hline & & NDFI & DMI & DEI & $\mathrm{F}$ & $\mathrm{R}$ & $\mathrm{OA}$ & Idle & SLE & $\mathrm{D}$ & FF & NM & FE & NDFRE \\
\hline \multirow[t]{2}{*}{ DMI } & $\mathrm{R}$ & 0.80 & & & & & & & & & & & & \\
\hline & $\mathrm{P}$ & 0.0001 & & & & & & & & & & & & \\
\hline \multirow[t]{2}{*}{ DEI } & $\mathrm{R}$ & 0.44 & 0.81 & & & & & & & & & & & \\
\hline & $\mathrm{P}$ & 0.0001 & 0.0001 & & & & & & & & & & & \\
\hline \multirow[t]{2}{*}{$\mathrm{F}$} & $\mathrm{R}$ & 0.38 & 0.20 & -0.15 & & & & & & & & & & \\
\hline & $\mathrm{P}$ & 0.0004 & 0.0741 & 0.1764 & & & & & & & & & & \\
\hline \multirow[t]{2}{*}{$\mathrm{R}$} & $\mathrm{R}$ & 0.20 & 0.25 & 0.35 & -0.19 & & & & & & & & & \\
\hline & $\mathrm{P}$ & 0.0492 & 0.0234 & 0.0012 & 0.0910 & & & & & & & & & \\
\hline \multirow[t]{2}{*}{$\mathrm{OA}$} & $\mathrm{R}$ & -0.30 & -0.22 & -0.26 & -0.34 & -0.87 & & & & & & & & \\
\hline & $\mathrm{P}$ & 0.0004 & 0.0470 & 0.0191 & 0.0016 & 0.0001 & & & & & & & & \\
\hline \multirow[t]{2}{*}{ Idle } & $\mathrm{R}$ & -0.02 & 0.05 & 0.06 & -0.11 & -0.70 & 0.73 & & & & & & & \\
\hline & $\mathrm{P}$ & 0.3601 & 0.4666 & 0.5637 & 0.3163 & 0.0001 & 0.0001 & & & & & & & \\
\hline \multirow[t]{2}{*}{ SLE } & $\mathrm{R}$ & -0.01 & -0.08 & 0.27 & 0.01 & 0.02 & -0.01 & 0.44 & & & & & & \\
\hline & $\mathrm{P}$ & 0.9366 & 0.3329 & 0.0128 & 0.9287 & 0.9515 & 0.9168 & 0.0001 & & & & & & \\
\hline \multirow[t]{2}{*}{$\mathrm{D}$} & $\mathrm{R}$ & -0.08 & -0.01 & 0.08 & -0.04 & 0.08 & -0.06 & -0.32 & 0.09 & & & & & \\
\hline & $\mathrm{P}$ & 0.4536 & 0.5922 & 0.4534 & 0.6863 & 0.4410 & 0.5971 & 0.0028 & 0.4196 & & & & & \\
\hline \multirow[t]{2}{*}{$\mathrm{FF}$} & $\mathrm{R}$ & 0.18 & 0.11 & -0.02 & 0.29 & -0.12 & -0.03 & -0.05 & -0.07 & 0.32 & & & & \\
\hline & $\mathrm{P}$ & 0.1667 & 0.3490 & 0.8603 & 0.0083 & 0.2567 & 0.8007 & 0.6264 & 0.5411 & 0.0031 & & & & \\
\hline \multirow[t]{2}{*}{ NM } & $\mathrm{R}$ & 0.31 & 0.11 & -0.01 & 0.54 & -0.22 & -0.07 & 0.03 & -0.13 & 0.19 & 0.64 & & & \\
\hline & $\mathrm{P}$ & 0.0067 & 0.3414 & 0.9694 & 0.0001 & 0.0495 & 0.5066 & 0.7534 & 0.2453 & 0.0802 & 0.0001 & & & \\
\hline \multirow[t]{2}{*}{$\mathrm{FE}$} & $\mathrm{R}$ & -0.06 & 0.27 & 0.46 & -0.87 & 0.26 & 0.21 & 0.07 & -0.03 & 0.01 & -0.27 & -0.52 & & \\
\hline & $\mathrm{P}$ & 0.5174 & 0.0293 & 0.0001 & 0.0001 & 0.0216 & 0.0657 & 0.4929 & 0.7869 & 0.9947 & 0.0157 & 0.0001 & & \\
\hline \multirow[t]{2}{*}{$\mathrm{RE}$} & $\mathrm{R}$ & 0.28 & 0.31 & 0.20 & 0.26 & -0.82 & 0.64 & 0.63 & -0.03 & -0.09 & 0.17 & 0.31 & -0.09 & \\
\hline & $\mathrm{P}$ & 0.0101 & 0.0055 & 0.0757 & 0.0177 & 0.0001 & 0.0001 & 0.0001 & 0.7812 & 0.4059 & 0.1299 & 0.0048 & 0.4103 & \\
\hline \multirow[t]{2}{*}{ NDFRE } & $\mathrm{R}$ & 0.41 & 0.69 & 0.13 & 0.45 & -0.55 & 0.29 & 0.43 & -0.02 & -0.13 & 0.22 & 0.45 & -0.25 & 0.85 \\
\hline & $\mathrm{P}$ & 0.0001 & 0.0001 & 0.2130 & 0.0001 & 0.0001 & 0.0066 & 0.0001 & 0.8764 & 0.2490 & 0.0471 & 0.0001 & 0.272 & 0.0001 \\
\hline
\end{tabular}

DMI - dry matter intake; DEI - digestible energy intake; NDFI - neutral detergent fiber intake; F - feeding; R - rumination; OA- other activities; SLE - sleeping; $\mathrm{D}$ - frequency at drinking trough; FF - feeding frequency; NM - number of meals; FE - feeding efficiency; RE and NDFRE - rumination efficiency of dry matter and neutral detergent fiber, respectively.

inclusion of the by-product only at the lowest concentrate level (Table 6). These results were reflections of the association of the greater quantity of roughage and reduced density of the babassu mesocarp meal in these diets, which made it difficult for the animal to pick up the feed and thus increased the feeding time. It is emphasized that feeding efficiency where the animal picks up the feedstuff is determined by the time allocated for intake, specific weight of the feed (Van Soest, 1994), variation in the fibrous components of the diet (Silva et al., 2005) and type of roughage in the diet (Pinto et al., 2010).

Feeding efficiency was positively correlated $(\mathrm{P}<0.05)$ with dry matter intake $(r=0.87)$, feeding frequency $(r=-0.27)$ and number of meals $(\mathrm{r}=-0.52)$, implying that more efficient animals need less time for feed intake, fewer visits to the feeder and a small number of meals/day to meet their nutritional requirements.

Rumination time decreased $(\mathrm{P}<0.05)$ with the increase in concentrate level in the diets without babassu mesocarp meal (Table 7), results associated to the small participation of the neutral detergent fiber coming from the forage. These results were in line with Van Soest (1994), who reported that rumination time was influenced by the nature of the diet and proportional to the cell wall content of the roughage, and was increased by the increase in fiber in the diet. On the other hand, rumination time was not altered $(\mathrm{P}>0.05)$ by the concentrate level in the diets with babassu mesocarp meal, a result possibly associated to the similar dry matter intake in these diets.

The rumination time was correlated $(\mathrm{P}<0.05)$ with the time allocated for other activities $(r=-0.87)$ and idleness $(r=-0.70)$, indicating that the animals gave up rest time for rumination, because they needed to maintain their energy intake, in the case of the diets containing babassu mesocarp meal (Table 5). Other correlations were also significant; rumination time with efficiency of dry matter rumination $(r=-0.82)$ and neutral detergent fiber $(r=-0.55)$, showing that the increase in rumination time negatively influenced the rumination efficiency. The results of the present study were in line with those presented in the literature (Bürger et al., 2000; Pereira et al., 2009; Missio et al., 2010) for the same animal category, where the authors reported variation from 4.23 to 8.96 hours/day, which was a reflection of the quantity of roughage used in the diets, the size of the roughage particle and the diet composition.

Dry matter rumination efficiency increased $(\mathrm{P}<0.05)$ with the inclusion of babassu mesocarp meal and the increased concentrate level improved this characteristic only in the diets without babassu mesocarp meal (Table 7). Neutral detergent fiber rumination efficiency increased for 
Table 6 - Variables related with feeding frequency, number of meals and feeding efficiency according to the factors assessed BMM in the concentrate

\begin{tabular}{|c|c|c|c|c|}
\hline (g/kg DM) & \multicolumn{2}{|c|}{ Concentrate level in diet $(\mathrm{g} / \mathrm{kg} \mathrm{DM})$} & Mean & $\mathrm{CV}(\%)$ \\
\hline \multicolumn{5}{|c|}{ Feeding frequency* } \\
\hline 0 & $11.62 \mathrm{Bb}$ & $14.81 \mathrm{Aa}$ & 13.21 & \\
\hline 350 & $15.57 \mathrm{Aa}$ & $15.09 \mathrm{Aa}$ & 15.33 & 23.25 \\
\hline Mean & 13.59 & 14.95 & 14.27 & \\
\hline \multicolumn{5}{|c|}{ Number of meals/day* } \\
\hline 0 & $7.00 \mathrm{Ba}$ & $7.67 \mathrm{Aa}$ & 7.33 & \\
\hline 350 & $9.43 \mathrm{Aa}$ & $8.71 \mathrm{Aa}$ & 9.07 & 28.72 \\
\hline Mean & 8.21 & 8.19 & 8.20 & \\
\hline \multicolumn{5}{|c|}{ Feeding efficiency, $\mathrm{kg}$ DM/hour* } \\
\hline 0 & $3.41 \mathrm{Aa}$ & $3.44 \mathrm{Aa}$ & 3.43 & 20.59 \\
\hline
\end{tabular}

* Interaction $(\mathrm{P}<0.05)$ between the factors assessed.

BMM - babassu mesocarp meal; DM - dry matter

Means followed by different letters (uppercase in the column and lowercase in the row) differ $(\mathrm{P}<0.05)$ by Tukey's test.

Table 7 - Variables related with the rumination time and rumination efficiency according to the factors studied BMM in the concentrate

\begin{tabular}{|c|c|c|c|c|}
\hline \multirow[t]{2}{*}{$(\mathrm{g} / \mathrm{kg} \quad \mathrm{DM})$} & \multicolumn{2}{|c|}{ Concentrate level in the diet $(\mathrm{g} / \mathrm{kg} \mathrm{DM})$} & \multirow[t]{2}{*}{ Mean } & \multirow[t]{2}{*}{$\mathrm{CV}(\%)$} \\
\hline & 650 & 710 & & \\
\hline \multicolumn{5}{|c|}{ Rumination time, $\mathrm{min} /$ day* } \\
\hline 0 & $452.14 \mathrm{Aa}$ & $409.76 \mathrm{Ab}$ & 430.95 & 16.18 \\
\hline 350 & $420.48 \mathrm{Aa}$ & $398.09 \mathrm{Aa}$ & 409.29 & \\
\hline Mean & 436.31 & 403.93 & 420.12 & \\
\hline 0 & $1.27 \mathrm{Bb}$ & $1.42 \mathrm{Ba}$ & 1.34 & \\
\hline 350 & $1.48 \mathrm{Aa}$ & $1.61 \mathrm{Aa}$ & 1.55 & 15.64 \\
\hline Mean & 1.38 & 1.51 & 1.44 & \\
\hline \multicolumn{5}{|c|}{ Rumination efficiency, kg NDF/hour } \\
\hline 0 & 0.38 & 0.36 & $0.37 \mathrm{~B}$ & \\
\hline
\end{tabular}

* Interaction $(\mathrm{P}<0.05)$ between the factors assessed.

BMM - babassu mesocarp meal; DM - dry matter; NDF - neutral detergent fiber.

Means followed by different letters (uppercase in the column and lowercase in the row) differ $(\mathrm{P}<0.05)$ by Tukey's test.

the animals fed babassu mesocarp meal and was not altered by the concentrate level in the diet. Missio et al. (2010) observed that rumination efficiency improved with increase in the concentrate content in the diet, because this characteristic is associated to the greater specific weight of the concentrate fraction and the neutral detergent fiber contents of the diet, where the regurgitated cud, in diets with greater concentrate proportions, is heavier and has less fiber. This fact allows the animal to give a smaller number of chews per cud and ruminate fewer cuds per day. In diets with lower concentrate proportions, the quantity of cuds per day and chews/cud normally increases because the regurgitated cud is lighter, but has greater volume, because it consists mostly of forage.

Time allocated for other activities was reduced by including babassu mesocarp meal in the diet (Table 8), a result of the increase in feeding and rumination time. These results were in line with those by Hodgson (1990) who reported that the daily activities of the animals are exclusionary, where increase in feeding or rumination reduces idleness.

The increase in time for other activities in function of concentrate level in the diets was in line with findings by Silva et al. (2005) and Missio et al. (2010). It is emphasized 
that resting time allocation is related to the comfort of the animal, in which longer rest periods can determine greater animal performance (Souza et al., 2007; Missio et al., 2010) because increase in rest time represents decrease in physical activity, which uses energy, and can decrease the energy requirements for maintenance (Missio et al., 2010).

The time spent on other activities was negatively correlated $(\mathrm{P}<0.05)$ with neutral detergent intake $(\mathrm{r}=-0.32)$, feeding time $(r=-0.34)$ and rumination $(r=-0.87)$, showing the need of the animal to decrease its rest to maintain nutrient intake, consequently increasing mastication by rumination. Furthermore, the time used for other activities was correlated $(\mathrm{P}<0.05)$ with the dry matter rumination efficiency $(\mathrm{r}=0.64)$ and neutral detergent fiber intake $(\mathrm{r}=0.29)$, showing that greater energetic content in the diets was better able to meet the nutritional requirements, provided greater flexibility for organizing the feeding activities and better comfort conditions, by increasing the rest time. In this sense, it was observed that idle time was shorter $(\mathrm{P}<0.05)$ for the diets that associated the lowest concentrate level and inclusion of $350 \mathrm{~g} / \mathrm{kg}$ of dry matter of babassu mesocarp meal (Table 8), resulting from the need to increase the feeding time and maintain the nutrient intake level.

The time the animals slept was shorter $(\mathrm{P}<0.05)$ for the diets containing babassu mesocarp meal at the highest concentrate level (Table 8). These results can be considered atypical, because the longer rest period occurred in the diets without byproduct. On the other hand, the animals slept longer $(\mathrm{P}<0.05)$ as the concentrate level increased in the diets containing babassu mesocarp meal, a fact that may have been associated to the greater digestible energy intake. It is emphasized that the time that the animals slept was correlated $(\mathrm{P}<0.05)$ with the digestible energy intake $(r=0.27)$ and idleness $(r=0.44)$, showing that the increase in energy intake resulted in longer rest time.

The frequencies of the animals at the drinker increased $(\mathrm{P}<0.05)$ with the increase in concentrate contents in the diet without babassu mesocarp meal and decreased in diets containing $350 \mathrm{~g} / \mathrm{kg}$ dry matter of this byproduct in the concentrate (Table 8). The increase in frequency at the drinker with increased concentrate level in the diets without babassu mesocarp meal may have been related to the low water content in these diets (Table 1). Lower moisture content in diets can determine low water ingestion associated to the feed, a fact that encourages the animal to ingest water, as reported by Phillips (2004). On the other hand, decrease in frequency to the drinker with increase in concentrate in the diets containing babassu mesocarp meal may have been related to the needs of the animals to increase feed ingestion to meet their energetic requirement. These interferences were evident from the correlation $(\mathrm{P}<0.05)$ of the frequency to the drinker with idleness $(\mathrm{r}=0.32)$ and feeding frequency $(\mathrm{r}=0.32)$, indicating that rest time decreased in function of increase in water intake

Table 8 - Variables related with idleness, water intake and other activities according to the factors studied

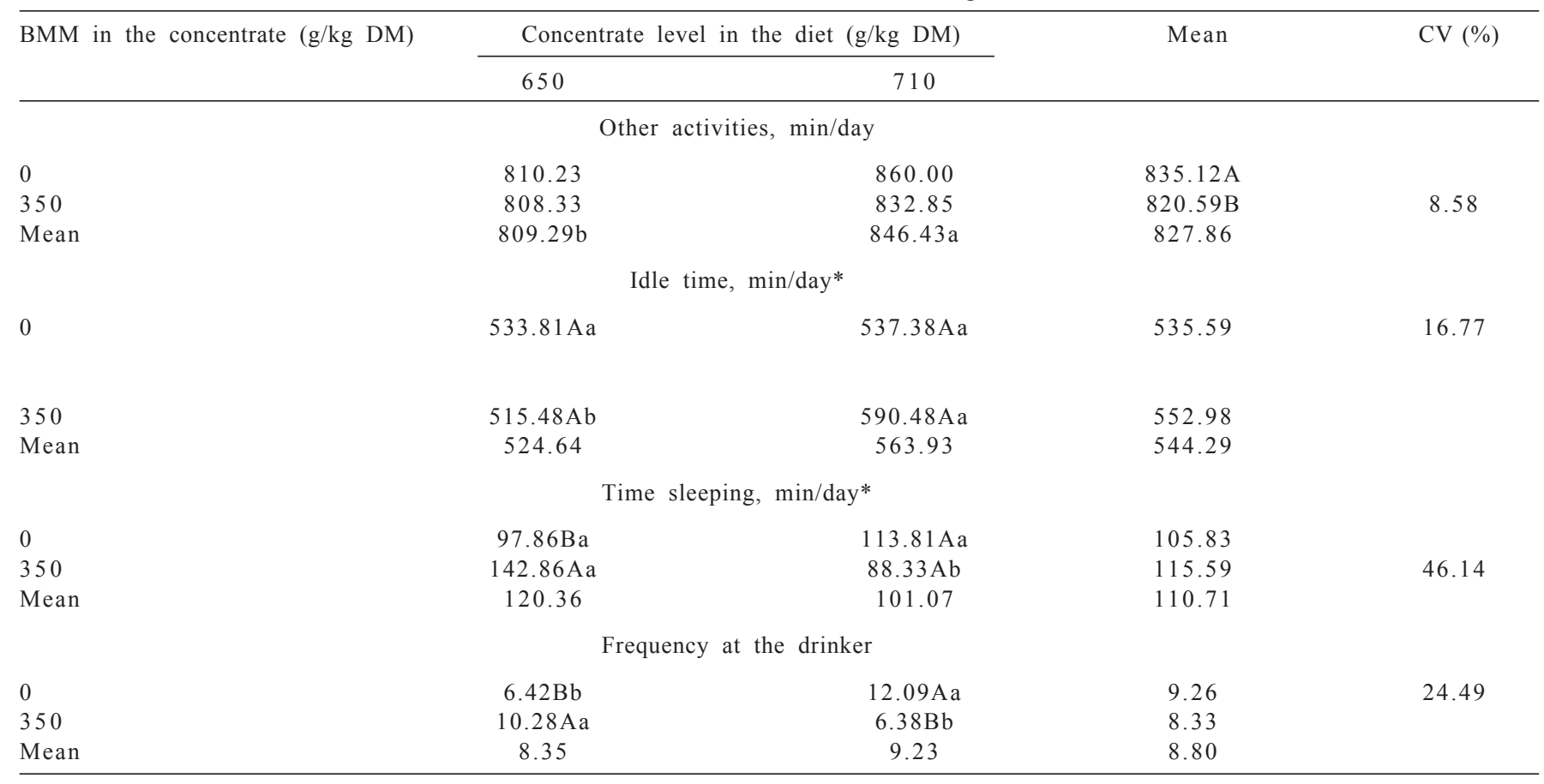

* Interaction $(\mathrm{P}<0.05)$ between the factors assessed.

BMM - babassu mesocarp meal; DM - dry matter.

Means followed by different letters (uppercase in the column and lowercase in the row) differ $(\mathrm{P}<0.05)$ by Tukey's test. 
resulting from the increase in feed intake. These assumptions are in line with the results obtained by Portugal et al. (2000), who observed that water intake in primipara and multipara dairy cows feedlot-fed followed the dry matter ingestion.

The number of daily ruminated cuds and the number of chews per cud were not altered $(\mathrm{P}>0.05)$ by the factors assessed (Table 9), which were close to those reported in the literature, because normally 360 to 790 cuds are ruminated and there can be on average 40 to 70 jaw movements (chews) during cud rumination (Furlan et al., 2006).

The number of daily chews and daily mastication time decreased $(\mathrm{P}<0.05)$ with the increase in the concentrate level in the diet without babassu mesocarp meal in the concentrate (Table 9) a fact associated to dry matter intake and the quantity of fiber in the roughage. It is worth stressing that chewing the feed reduces the particle size, increases its density and its reticulum-rumen escape, and the efficiency of this process is influenced by dry matter intake (Ulyatt et al., 1986) and the diet fiber source (Mendes et al., 2010).

In the present study, in spite of increasing intake, there was no alteration in the number of chews/day and chewing time/day by including babassu mesocarp meal in the concentrate (Table 9). These results were associated to the characteristics of the byproduct at issue, because although it has high neutral detergent fiber content, its particles size are small, with $96 \%$ of the particles passing through a $1.18 \mathrm{~mm}$ sieve (Miotto, 2011). This fact characterizes the babassu mesocarp meal fiber as of low effectiveness, because according to Mertens (1997), the particles should have a minimum size of $1.18 \mathrm{~mm}$ to stimulate rumination. According to a literature review by Allen (1997), the daily chewing time is around 11.13 hours. In the present study the values found were below the abovementioned value, a fact that may have been associated to the high concentrate contents used.

The daily chewing time was correlated $(\mathrm{P}<0.05)$ with the intakes of digestible energy $(\mathrm{r}=0.26)$, dry matter $(\mathrm{r}=0.34)$, neutral detergent fiber $(\mathrm{r}=0.39)$, rumination time $(\mathrm{r}=0.86)$ and other activities $(\mathrm{r}=0.99)$. These correlations showed that daily mastication time was directly associated to the quantity of feed ingested and time allocated for rumination and inversely related to resting time. This can be further emphasized by the correlation $(\mathrm{P}<0.05)$ of the dry matter intake with the number of daily ruminated cuds $(\mathrm{r}=-0.24)$ and number of daily chews ( $\mathrm{r}=-0.32)$, showing that the animals adjust their feeding behavior in function of feed intake. These results agree with the literature because rumination

Table 9 - Variables related to the number of cud, chews per cud and chewing time according to the factors assessed

\begin{tabular}{|c|c|c|c|c|}
\hline BMM in the concentrate $(\mathrm{g} / \mathrm{kg} \mathrm{DM})$ & \multicolumn{2}{|c|}{ Concentrate level in the diet $(\mathrm{g} / \mathrm{kg} \mathrm{DM})$} & Mean & CV $(\%)$ \\
\hline \multicolumn{5}{|c|}{ Number of cuds ruminated/day } \\
\hline 0 & 465.46 & 428.18 & 446.82 & 19.24 \\
\hline 350 & 445.58 & 421.87 & 433.72 & \\
\hline Mean & 455.52 & 425.02 & 440.27 & \\
\hline 0 & 51.476 & 48.43 & 49.95 & 15.28 \\
\hline 350 & 48.76 & 46.91 & 47.83 & \\
\hline Mean & 50.12 & 47.67 & 48.89 & \\
\hline \multicolumn{5}{|c|}{ Number of daily chews* } \\
\hline 0 & $23587.08 \mathrm{Aa}$ & $20649.53 \mathrm{Ab}$ & 22118.30 & \\
\hline 0 & 60.09 & 58.57 & 59.33 & \\
\hline 350 & 57.09 & 57.48 & 57.29 & 16.98 \\
\hline Mean & 58.59 & 58.02 & 58.31 & \\
\hline \multicolumn{5}{|c|}{ Daily chewing time, hours* } \\
\hline 0 & $10.50 \mathrm{Aa}$ & $9.67 \mathrm{Ab}$ & 10.08 & \\
\hline 350 & $10.53 \mathrm{Aa}$ & $10.12 \mathrm{Aa}$ & 10.32 & 11.60 \\
\hline Mean & 10.51 & 9.89 & 10.20 & \\
\hline
\end{tabular}

*Interaction $(\mathrm{P}<0.05)$ between the factors assessed

BMM - babassu mesocarp meal; DM - dry matter.

Means followed by different letters (uppercase in the column and lowercase in the row) differ $(\mathrm{P}<0.05)$ by Tukey's test. 
can reduce the time allocated to daily mastication with increase in efficiency in particle reduction (Deswysen et al., 1987), increase in the proportion of jaw movements in relation to the number of total movements (Deswysen \& Ehrlein, 1981), reduction in the interval between cud rumination (Gordon, 1965), increase in the jaw movement rate (Bae et al., 1981) or by their interaction.

\section{Conclusions}

Including babassu mesocarp meal in the diet altered the feeding behavior of the feedlot cattle because they had to increase their feeding time to maintain energy intake. The alterations in feeding behavior in order to maintain energy intake were facilitated in diets with higher concentrate contents and when more resting time was available.

\section{Acknowledgements}

The authors of this article thank Capes for financing this project.

\section{References}

ALLEN, M.S. Relationship between fermentation acid production in the rumen and the requirement for physically effective fiber. Journal of Dairy Science, v.80, n.7, p.1447-1462, 1997

ARAÚJO, G.G.L.; SILVA, J.F.C.; CAMPOS, S. et al. Consumo e digestibilidade total dos nutrientes de dietas contendo diferentes níveis de volumoso, em bezerros. Revista Brasileira de Zootecnia, v.27, n.2, p.345-354, 1998 .

ASSOCIATION OF OFFICIAL ANALYTICAL CHEMISTS - AOAC. Official methods of analysis. 16.ed. Arlington: AOAC International, 1995. 1025p.

BAE, D.H.; WELCH, J.; SMITH, A.M. et al. Efficiency of mastication in relation to hay intake by cattle. Journal of Animal Science, v.52, n.6, p.1371-1375, 1981

BEAUCHEMIN, K.A. Effects of dietary neutral detergent fiber concentration and alfalfa hay quality on chewing, rumen function, and milk production of dairy cows. Journal of Dairy Science, v.74, n.9, p.3140-3151, 1991.

BÜRGER, P.J.; PEREIRA, J.C; QUEIROZ, A.C. et al. Comportamento ingestivo em bezerros holandeses alimentados com dietas contendo diferentes níveis de concentrado. Revista Brasileira de Zootecnia, v.29, n.1, p.236-242, 2000.

DADO, R.G.; ALLEN, M.S. Intake limitations, feeding behavior, and rumen function of cows challenged with rumen fill from dietary fiber or inert bulk. Journal of Animal Science, v.78, n.1, p.118-133, 1995.

DESWYSEN, A.G.; ELLIS, W.C.; POND, K.R. Interrelationship among voluntary intake, eating and ruminating behavior and ruminal motility of heifers fed corn silage. Journal of Animal Science, v.71, n.3, p.835-841, 1987.

DESWYSEN, A.G.; EHRLEIN, H.J. Silage intake, rumination and pseudoruination activity in sheep studied by radiography and jaw movements recordings. British Journal Nutrition, v.46, p.327-336, 1981

FURLAN, R.I.; MACARI, M.; FARIA FILHO, D.E. Anatomia e fisiologia do trato gastrintestinal. In: BERCHIELLI, T.T.;
PIRES, A.V.; OLIVEIRA, S.G. (Eds.) Nutrição de ruminantes. Jaboticabal: Funep, 2006. p.1-21.

GORDON, J.G. The relationship between rumination and the amount of roughage eaten by sheep. Journal of Animal Science, v.64, n.2, p.151-155, 1965.

HODGSON, J. Grazing management: science into practice. Inglaterra: Longman Handbooks in Agriculture, 1990. 203p.

MARTIN, P.; BATESON, P. Measuring behavior and introductory guide. 3.ed. New York: Cambridge University Press, 1986. 254p

MENDES, C.Q.; TURINO, V.C.; SUSIN, I. et al. Comportamento ingestivo de cordeiros e digestibilidade dos nutrientes de dietas contendo alta proporção de concentrado e diferentes fontes de fibra em detergente neutro. Revista Brasileira de Zootecnia, v.39, n.3, p.594-600, 2010

MERTENS, D.R. Creating a system for meeting the fiber requirements of dairy cows. Journal of Dairy Science, v. 80 , n.7, p.1463-1481, 1997.

MIOTTO, F.R.C. Farelo do mesocarpo de babaçu na produção de bovinos de corte. 2011. 158f. Tese (Doutorado em Zootecnia) - Universidade Federal de Goiás, Goiânia.

MISSIO, R.L.; BRONDANI, I.L.; ALVES FILHO, D.C. et al Comportamento ingestivo de tourinhos terminados em confinamento, alimentados com diferentes níveis de concentrado na dieta. Revista Brasileira de Zootecnia, v.39, n.7, p.1571-1578, 2010.

NATIONAL RESEARCH COUNCIL - NRC. Nutrients requirements of beef cattle. 7.ed. Washington, D.C.: 1996. 242p.

PENNING, P.D.; ROOK, A.J.; ORR, R.J. Patterns of ingestive behavior of sheep continuously stocked on monocultures of ryegrass or white clover. Applied Animal Behavior Science, v.31, n.3, p.237-250, 1991.

PEREIRA, E.S.; MIZUBUTI, I.Y.; RIBEIRO, E.L.A. et al. Consumo, digestibilidade aparente dos nutrientes e comportamento ingestivo de bovinos da raça Holandesa alimentados com dietas contendo feno de capim-tifton 85 com diversos tamanhos de partícula. Revista Brasileira de Zootecnia, v.38, n.1, p.190-195, 2009.

PHILLIPS, C.J.C. The effects of forage provision and group size on the behavior of calves. Journal of Dairy Science, v.87, n.5, p.1380-1388, 2004.

PINTO, A.P.; MARQUES, J.A.; ABRAHÃO, J.J.S. et al Comportamento e eficiência ingestiva de tourinhos mestiços confinados com três dietas diferentes. Archivos de Zootecnia, v.59, n.227, p.427-434, 2010.

PIRES, M.F.A.; VILELA, D.; ALVIM, M.J. Instrução técnica para o produtor de leite: comportamento alimentar de vacas holandesas em sistemas de pastagem ou em confinamento Coronel Pacheco: Embrapa Gado de Leite, 2001. 2p.

POLLI, V.A.; RESTLE, J.; SENNA, D.B. et al. Aspectos relativos à ruminação de bovinos e bubalinos em regime de confinamento. Revista Brasileira de Zootecnia, v.25, n.5, p.987-993, 1996.

PORTUGAL, J.A.B.; PIRES, M.F.A.; DURÃES, M.C. Efeito da temperatura ambiente e da umidade relativa do ar sobre a frequência de ingestão de alimentos e de água e de ruminação em vacas da raça Holandesa. Arquivo Brasileiro de Medicina Veterinária e Zootecnia, v.52, n.2, p.154-159, 2000.

RAMONET, Y.; MEUNIER-SALUAN, M.C.; DOURMAD, J.Y High-fiber diets in pregnant sows: Digestible utilization and effects on the behavior of the animals. Journal of Animal Science, v.77, n.3, p.591-599, 1999.

SILVA, D.J.; QUEIROZ, C.A. Análise de alimentos (métodos químicos e biológicos). 2.ed. Viçosa, MG: Imprensa Universitária, 2002. 165 p.

SILVA, R.R.; SILVA, F.F.; CARVALHO, G.G.P. et al. Comportamento ingestivo de novilhas mestiças de holandês $\mathrm{x}$ zebu confinadas. Archivos de Zootecnia, v.54, n.205, p.75-85, 2005.

SOUZA, S.R.M.B.O.; ÍTAVO, L.C.V.; RÍMOLI, J. et al. Comportamento ingestivo diurno de bovinos em confinamento e em pastagens. Archivos de Zootecnia, v.56, n.213, p.67-70, 2007.

SNIFFEN, C.J.; O'CONNOR, J.D.; VAN SOEST, P.J. et al. A net carbohydrate and protein system for evaluating cattle diets: II. 
Carbohydrate and protein availability. Journal of Animal Science, v.70, p.3562-3577, 1992.

TILLY, J.M.A., TERRY, R.A. A two-stage technique for the "in vitro" digestion of forage crops. Journal of the British Grassland Society, v.18, n.2, p.104-111, 1963.

ULYATT, M.J.; DELLOW, D.W.; JOHN, A. et al. Contribution of chewing during eating and rumination as the clearance of digesta from the rumino-reticulum. In: MILLIGAN, L.P.; GROVUM, W.L; DOBSON, A. (Eds.) Control of digestion and metabolism in ruminants. INTERNACIONAL SYMPOSIUM ON RUMINANT PHYSiOlOGY, 6., 1984, Canada. Proceedings... Englewood Cliffs: Prentice-Hall, 1986. p.498-515.
VAN SOEST, P.J. Collaborative study of acid detergent fiber and lignin. Journal of the Association of Official Analytical Chemists, v.56, p.81-784, 1973.

VAN SOEST, P.J. Nutritional ecology of the ruminant. 2.ed. New York: Cornell University Press, 1994. 476p.

VAN SOEST, P.J.; ROBERTTSON, J.B.; LEWIS, B.A. Methods for dietary fiber, neutral detergent fiber, and nonstarch polysaccharides in relation to animal nutrition. Journal of Dairy Science, v.74, n.10, p.3583-3597, 1991 .

WILKINSON, J. Transformações e perspectivas dos agronegócios brasileiros. Revista Brasileira de Zootecnia, v.39, p.26-34, 2010 (supl. especial). 